\title{
Seasonal Variation of Water Pollutants in Hindon River
}

\author{
Neelima, Jyoti Singh \\ Department of Geography, J V Jain College Saharanpur-UP (INDIA)
}

\begin{abstract}
The present paper deals with the seasonal variation of pollutants present in Hindon River. We have focused on the chemical composition changes that are usually generated due to municipal and small scale industrial waste and its hazardous effect on the living beings. We have arranged the data in respect to seasonal variation i.e. winter, summer, rainy and after rainy season.
\end{abstract}

Keywords: Water Pollution, Health hazardous, Hindon River, Seasonal effects, pollutants etc.

\section{Introduction}

The present work is an analysis of water pollution of Hindon River. The main objective of the study is to study the water pollution intensity and thereby to study the variation due to climatic change as well as relationships among the different parameters of pollution and to examine changes in parameters. To examine the consequence of pollution generation over a period of time and also to examine the status of pollution control through different abatement techniques.

\section{Study Area}

The upper part of the river basin is in the area of Saharanpur district which has a large number of industries related to paper, milk products, distillery and small scale cottage industries pertaining to electroplating, paper board, chemicals, textile and rubber, etc. The waste effluents generated from these industries are released either directly on the lowlands or into the tributaries of the Hindon River in their vicinity. Much of these wastes contaminate the receiving water, especially in the stretches immediately downstream of their outfalls. The main effluent discharge in the upper part of the river system is from the Star Paper Mill, Saharanpur. The river has two major drains in Saharanpur, i.e. Nagdev nala and Dhamola nala, which join the Hindon near the village of Ghogreki and Sadhauli Hariya, respectively. The municipal wastewater generated from the Saharanpur city is discharged to Hindon River through Dhamola nala. There is no wastewater treatment system in the city. Although Yamuna Action plant is in the city but it is not in working condition. The wastes from several small units such as textile factory, sugar factory, cigarette factory, cardboard factory and laundries etc. also transfer their wastes to the Hindon through the Dhamola nala. The industrial effluent from the Cooperative Distillery also joins the river in this stretch. After Saharanpur region this river enters in Muzaffarnagar District area where it meets with Kali River which carries the municipal and industrial wastes of Muzaffarnagar district and joins the Hindon near the village of Atali. The Krishni River, receiving wastes from a sugar mill and distillery, joins the Hindon near the village of Barnawa, local drains from villages and towns also join the river. The characteristics of the various waste effluents discharged into the Hindon River have been discussed in (Jain et al.). The Hindon river water is not been used to drink also this is not fit for aquatic plants/species at any place in its course of flow.

\section{Analysis}

The river water is clear and odorless at an upstream site before Saharanpur. The first mainstream which joins this river is Paodhoi, although before merging in Hindon Paodhoi accompanying Municipal wastes of Saharanpur city and at Maheshpur the river has a foul and pungent organic odor due to the discharge of pulp and paper mill effluent. The odor becomes much more pronounced in the summer months due to high temperature. In addition to the floating froth and foam, the river water also becomes brown in color owing to the discharge of pulp and paper factory effluent. The water is dark brown at stations Barnawa due to discharge of municipal waste of Muzaffarnagar. The light black color of the water decreases the penetration of light and affects the spectrum of the light-wavelength. The change in the wavelength and its reduction in intensity limits the growth of aquatic plants/species which are of great importance, not only because of linkage in the food chain cycle of aquatic habitats, but also because of they produce oxygen by photosynthetic activity which plays an important role in re-aeration of streams and in natural self-purification processes.

The $\mathrm{pH}$ of the river water was always found towards the alkaline side at all the points and jumps in the month June and October and $\mathrm{pH}$ is maximum in October every year but is always between permissible values. The values of $\mathrm{pH}$ show almost the same trend in the flow of its length. The variation in $\mathrm{pH}$ at different stations is well within the range of tolerance by fish.

The DO values gradually increase in its flow due to reaeration and photosynthesis. The Kali River, carrying wastewater of municipal and industrial effluents of Muzaffarnagar district, meets the Hindon at Atali village. A substantial amount of water is discharged in the Kali from the Upper Ganga Canal at Khatauli. The level of dissolved oxygen in the Hindon after the confluence with the Kali increase further, and it is observed that DO decreases during 


\section{International Journal of Science and Research (IJSR) \\ ISSN (Online): 2319-7064}

Index Copernicus Value (2013): 6.14 | Impact Factor (2015): 6.391

summer months w.r.t. during winters and it shows high in monsoon session. At Barnawa village, another tributary, the Krishni, joins the Hindon, which flows only (Oct. to March) during the sugar crushing in winter season and remains dry for the rest of the year. The quality of the river water is controlled by the discharge of water from the Upper Ganga Canal through the Khatauli and Jani escapes. Around $65 \%$ of the data points are less than the average DO value. It may be however notice that high level of DO (brown color) appears during summer months due to high temperature. This is contrary to the basic concept of solubility of gases in water as a function of temperature.

The contents of total dissolved solids i.e. Hardness, vary between 246 to $340 \mathrm{mg} / \mathrm{L}$ in the upstream section at Maheshpur village due to the mixing of effluent from the Star Paper Mill, municipal waste and Cooperative Distillery. The excess dissolved solids create an imbalance due to increased turbidity and causes suffocation of fish even in the presence of high dissolved oxygen in low temperature session. The dissolved solids decreased considerably at Barnawa due to Ganga canal water and a long flow area throughout the year. A slight increase in dissolved solids was observed at station Mohannagar due to the discharge of wastewater from the Ghaziabad Municipal and industrial effluents of Mohannagar area, which then indicated a slight decreasing trend in the downstream section of the river.

However, the distribution of Biological Oxygen Demand (BOD) at all the stations is not the same. The BOD content gets reduced about to 4.60 at station Mohannagar during summer months so that a complete anaerobic condition is developed. This indicates that the river flow is mainly composed of the wastewater generated from industries. The overall BOD values vary from 12.00 to $22.11 \mathrm{mg} / \mathrm{L}$ in the upstream section of the Hindon at the village of Maheshpur. However, a sudden slowdown in the BOD values was observed in the flow. The higher values of BOD observed at these stations indicate a high degree of organic pollution in this stretch of the river. The effluent of pulp and paper mill and distillery adds to the high concentration of organic matter in the river, which is responsible for a remarkable decrease in DO, along with increase in BOD, COD and TDS. From station Barnawa, the oxygen condition improves significantly with the lowering of BOD values. Upstream of Atali village, the Hindon has little flow due to significant abstraction for irrigation by the farmers along its course. At Barnawa village, the Kali joins the Hindon and the water quality of the Hindon is controlled by the inputs from the Kali. The Kali also receives a significant amount of water from the Upper Ganga Canal through the Khatauli escape.

The COD values range from 25.0 to $66.0 \mathrm{mg} / \mathrm{L}$ in its flow. However, a sudden rise in COD values was observed at stations Maheshpur due to the discharge of paper mill and distillery effluents. Also the high values of COD observed at stations Barnawa indicate a certain degree of organic pollution in this stretch of the river. The effluent of the Pulp \& Paper mill and the distillery a high concentration of organic matter to the river, which is responsible for a remarkable decrease in DO, along with an increase in COD values. From station Maheshpur to Barnawa, the oxygen condition improves significantly due to re-aeration, resulting in the lowering of COD values. At station Barnawa again, the values of COD rise while DO decreases due to the confluence of the Budhana drain and Kali into the Hindon. From station Barnawa to Mohannagar, the COD values show a slight decreasing trend due to the re-aeration and dilution effect of water from Upper Ganga Canal.

Alkalinity displayed consistent seasonal behavior, which may be attributed to biological activities caused by topographic, microclimatic and different amounts of wastes discharged to the river. Significantly, lower alkalinity in the monsoon months, at Maheshpur, although about 3 to 4 times alkalinity is registered in the non-monsoon session.

The conductivity of liquid depends upon temperature and metal particle concentration. The concentration of metal composition in the upstream section at Maheshpur village is remarkable very high due to the confluence of Municipal waste of Saharanpur is the only source of water, and also maintain its high till Barnawa but after discharge of Ganga canal water it dilute and got significantly low throughout flow afterward and again increase after Noida.

The maximum value of Turbidity was observed in Monsoon session at Station Barnawa was found to be 121, which reduces to up to 8.0 at Station Mohannagar due to addition of fresh water of Ganga Canal. Again at Station Noida and Daruhera it increases.

The Total Coliform is the presence of bacterial parasites present in water. It depends on DO and concentration of natural organic salts presents in water. Here data shows that the concentration of Total coliform increases with the decrease of OD and increase of BOD \& COD.

\section{Conclusion}

The river is sluggish in whole year except during the high flow period or in monsoon session. It is evident that during a high flow period, there is no significant effect of pollution owing to a very high dilution of the effluent, but once the flow decreases, there is visible sign of pollution, specifically during summer months. Hence the pollution load generated from Saharanpur city and industrial effluents of this region, viz. Star Paper Mill, Cooperative Distillery, Nagdev nala etc., is mainly responsible for the water quality degradation in the upper stretch of the Hindon River. There is a strong seasonal pattern for various water quality parameters in the river water with variation in concentrations during summer and during monsoon periods. Almost all of the constituents follow the same time patterns except DO, which shows a reverse pattern. The electrical conductivity of the river water underwent pronounced seasonal fluctuations with minimum values in winter and maximum values in late summer. This seasonal variation reflects that river water composition is influenced by annual cycles with biological and geological breakdown in the summer season which leads to the accumulation of chemicals during dry session, followed by dilution of those chemicals by monsoonal rainfall. 


\section{International Journal of Science and Research (IJSR) \\ ISSN (Online): 2319-7064}

Index Copernicus Value (2013): 6.14 | Impact Factor (2015): 6.391

\section{Suggestion's}

The river Hindon is polluted because of absence of, or negligence enforcement of water pollution control laws and regulations. If pollution control board enforce regulations on every industry, than about $70 \%$ pollution can be controlled but these agencies have very soft look for industries. But industry not takes it seriously therefore water treatment plant in these industries are only showpiece. Although establishment and functioning of water treatment plants is costly but anybody cannot play with the health of human beings. In the context of Saharanpur I saw that in a 2001 planning government has established a Yamuna action plant in Saharanpur city but when it was established it was working for sometimes only, but after 2-3 years it is almost non-working condition due to negligence of government agencies. Therefore our suggestion is valuable only when our intention is positive. But during this work I feel some following measure can be applied to decrease pollution level in River.

The Hindon river pollution control needs consideration of the following aspects for clean-up.

1)Domestic sewage due to residential colonies as well as hutments in the thickly populated area.

2)Industrial waste generated by authorized as well as unauthorized industries.

3) Animal waste due to household's animal sheds in various areas.

4) Garbage dumps by citizens all along its course.

5)Industrial sludge and rejects discarded material by recyclers at different points through is discourse.

To clean-up operation is thus a tedious effort if applied by government agencies. The steps to be taken to minimize pollution are as follows,

1) Provide sewerage system on both the banks of the river so that the sewage is collected and treated at various locations. This includes existing sewage discharge drains by rural and urban areas.

2)Immediately stop all the unauthorized industrial scrap dealers, scrap recyclers, waste oil recyclers etc. These industries contribute industrial waste, hazardous waste as well as sludge.

3) Provides proper garbage collection system on both banks, so that garbage is not dumped in the river.

4) To improve flow pattern, it is essential to clean the bed of Hindon river right from Nagdev Nala (Khajnawar) to Tilwara. This will improve its carrying capacity.

5)Plantation on the both the banks can result proper vegetation for beautification. In fact this will work as a natural eco-system to improve the quality of water and save cost of providing expensive treatment plants.

\section{References}

[1] Ahmed, I., and Umar. R., (2008), Hydrogeological framework and water balance studies in parts of Krishni-Yamuna interstream area, Western Uttar Pradesh, India. Environ Geology 53:1723-1730.

[2] Epic Proportion: Sardhana - There's more to Sardhana than the church., The Economic Times, Mar 6, 2008.

[3] Ghosh N. C., Mcbean E.A., (1998),"Water quality modelling of Kali River". India Water Air and Soil Pollution, 102(1-2), 91-103.

[4] Hindon Air Base GlobalSecurity.org "Sardhana There's more to Sardhana than the church". The Economic Times, Mar 6, 2008.

[5] Jain C.K. \& others "Hydro-Chemical Studies of Hindon River”, 1998-99, CS(AR)-21/98-99 National Institute of Hydrology, Roorkee.

[6] Jain C.K. \& others "Distribution of Heavy Metals on Sediments Under Different Flow Conditions", 19992000, TR/BR-8/99-2000, National Institute of Hydrology, Roorkee.

[7] Jain, C. K. and K. K. S. Bhatia; (1987), Physicochemical Analysis of Water and Wastewater. ser's Manual, UM-26, National Institute of Hydrology, Roorkee, India.

[8] Kumar B.,(1997), River Hindon and Tributaries : Assessment of Water Quality, ME Thesis, Department of Civil Engineering, IIT Roorkee.

[9] NRCR1995: Report on water quality monitoring of river Hindon under GAP Phase II, Dec. 1993-95, National River Conservation Directorate, Ministry of Environment and Forest, New Delhi, India

[10] NRCR1996: Report on water quality monitoring of river Hindon under GAP Phase II, Sep. 1995-Aug 1996, National River Conservation Directorate, Ministry of Environment and Forest, New Delhi, India

[11]NRCR1998: Report on water quality monitoring of river Hindon under GAP Phase II, Sep.1996 to Sep. 1998, National River Conservation Directorate, Ministry of Environment and Forest, New Delhi, India.

[12] NRCR2000: Report on water quality monitoring of river Hindon under GAP Phase II, Sep 1999- Aug. 2000, National River Conservation Directorate, Ministry of Environment and Forest, New Delhi, India.

[13] NRCR2001: Report on water quality monitoring of river Hindon under GAP Phase II, Sep. 2003-2005, National River Conservation Directorate, Ministry of Environment and Forest, New Delhi, India.

[14] NRCR2005: Report on water quality monitoring of river Hindon under GAP Phase II, Dec. 1993-95, National River Conservation Directorate, Ministry of Environment and Forest, New Delhi, India. 


\section{International Journal of Science and Research (IJSR) \\ ISSN (Online): 2319-7064}

Index Copernicus Value (2013): 6.14 | Impact Factor (2015): 6.391

Table 1: Consolidated Average Variation at Maheshpur in the gap of 1994-2005

\begin{tabular}{|c|c|c|c|c|c|c|}
\hline S.No. & Parameters & $\begin{array}{l}\text { January } \\
\text { Avarage }\end{array}$ & $\begin{array}{c}\text { June } \\
\text { Average }\end{array}$ & $\begin{array}{c}\text { August } \\
\text { Average }\end{array}$ & $\begin{array}{l}\text { October } \\
\text { Average }\end{array}$ & $\begin{array}{c}\text { Yearly } \\
\text { Average }\end{array}$ \\
\hline 1 & Air temperature $\mathrm{C}$ & 13.42 & 35.83 & 31.64 & 24.41 & 26.32 \\
\hline 2 & Water temperature $\mathbf{C}$ & 13.75 & 31.58 & 31.91 & 24.50 & 25.43 \\
\hline 3 & DO \% Saturation mg/L & 1.16 & 1.07 & 0.77 & 1.26 & 1.06 \\
\hline 4 & BOD mg/L & 22.11 & 19.95 & 11.94 & 12.30 & 16.57 \\
\hline 5 & COD mg/L & 66.29 & 54.96 & 45.25 & 43.99 & 52.62 \\
\hline 6 & $\mathrm{pH}$ & 7.69 & 7.84 & 7.77 & 7.90 & 7.80 \\
\hline 7 & Turbidity (NTU) & 28.93 & 11.55 & 50.17 & 19.58 & 27.56 \\
\hline 8 & Conductivity (mhos/cm) & 894.44 & 1035.05 & 609.99 & 880.34 & 854.95 \\
\hline 9 & $\begin{array}{c}\text { Total Coliform } \\
(\mathrm{mpn} / 100 \mathrm{ml})\end{array}$ & $7.29 \mathrm{E}+07$ & $3.34 \mathrm{E}+07$ & $8.06 \mathrm{E}+06$ & $1.92 \mathrm{E}+08$ & $7.65 \mathrm{E}+07$ \\
\hline 10 & Hardness (mg/L of CaCO3) & 339.92 & 295.42 & 246.55 & 323.73 & 301.40 \\
\hline 11 & Alkalinity (mg/L of $\mathrm{CaCO3})$ & 375.83 & 367.92 & 227.91 & 327.73 & 324.85 \\
\hline
\end{tabular}

Table 2: Consolidated Average Variation at Barnawa in the gap of 1994-2005

\begin{tabular}{|c|l|c|c|c|c|c|}
\hline S.No. & Parameters & January Avarage & June Average & August Average & October Average & Yearly Average \\
\hline $\mathbf{1}$ & Air temperature C & 14.83 & 38.21 & 32.95 & 29 & 28.75 \\
\hline $\mathbf{2}$ & Water temperature C & 14.29 & 32.88 & 29.14 & 25.73 & 25.51 \\
\hline $\mathbf{3}$ & DO $\%$ Saturation $\mathbf{~ m g / L ~}$ & 1.11 & 1.64 & 1.99 & 1.87 & 1.65 \\
\hline $\mathbf{4}$ & BOD $\mathbf{~ m g / L}$ & 16.65 & 13.66 & 6.6 & 10.46 & 11.84 \\
\hline $\mathbf{5}$ & COD $\mathbf{~ m g / L}$ & 61.57 & 66.16 & 50 & 50.6 & 57.08 \\
\hline $\mathbf{6}$ & $\mathbf{p H}$ & 7.62 & 7.77 & 7.75 & 8.02 & 7.79 \\
\hline $\mathbf{7}$ & Turbidity (NTU) & 17.5 & 46.38 & 121.27 & 22.72 & 51.97 \\
\hline $\mathbf{8}$ & Conductivity (mhos/cm) & 556.45 & 721.63 & 345 & 2834.47 & 1114.39 \\
\hline $\mathbf{9}$ & Total Coliform (mpn/100ml) & $3.51 \mathrm{E}+07$ & $1.99 \mathrm{E}+06$ & $2.60 \mathrm{E}+05$ & $4.23 \mathrm{E}+06$ & $1.04 \mathrm{E}+07$ \\
\hline $\mathbf{1 0}$ & Hardness (mg/L of CaCO3) & 265.79 & 179 & 166.09 & 273.36 & 221.06 \\
\hline $\mathbf{1 1}$ & Alkalinity (mg/L of CaCO3) & 286.79 & 221.75 & 153.82 & 248.45 & 227.7 \\
\hline
\end{tabular}

Table 3: Consolidated Average Variation at Mohannagar in the gap of 1994-2005

\begin{tabular}{|c|l|c|c|c|c|c|}
\hline S.No. & Parameters & January Avarage & June Average & August Average & October Average & Yearly Average \\
\hline $\mathbf{1}$ & Air temperature C & 18.58 & 36.79 & 32.59 & 31.36 & 29.83 \\
\hline $\mathbf{2}$ & Water temperature C & 15.17 & 29.96 & 31.09 & 27.27 & 25.87 \\
\hline $\mathbf{3}$ & DO \% Saturation mg/L & 2.38 & 2.77 & 2.95 & 8.46 & 4.14 \\
\hline $\mathbf{4}$ & BOD mg/L & 7 & 4.66 & 5.52 & 6.73 & 5.98 \\
\hline $\mathbf{5}$ & COD mg/L & 25.06 & 32.11 & 30.71 & 29.47 & 29.34 \\
\hline $\mathbf{6}$ & pH & 7.56 & 7.77 & 7.73 & 8.06 & 7.78 \\
\hline $\mathbf{7}$ & Turbidity (NTU) & 8.89 & 39.79 & 109.95 & 34.39 & 48.26 \\
\hline $\mathbf{8}$ & Conductivity (mhos/cm) & 449.35 & 601.34 & 278.36 & 444.94 & 443.49 \\
\hline $\mathbf{9}$ & Total Coliform (mpn/100ml) & $1.67 \mathrm{E}+08$ & $1.95 \mathrm{E}+05$ & $2.07 \mathrm{E}+06$ & $3.26 \mathrm{E}+05$ & $4.24 \mathrm{E}+07$ \\
\hline $\mathbf{1 0}$ & Hardness (mg/L of CaCO3) & 197.42 & 113.2 & 138.09 & 194.27 & 160.75 \\
\hline $\mathbf{1 1}$ & Alkalinity (mg/L of CaCO3) & 204.25 & 132.92 & 128.64 & 204.09 & 167.47 \\
\hline
\end{tabular}

Table 4: Consolidated Average Variation at Noida in the gap of 1994-2005

\begin{tabular}{|c|c|c|c|c|c|c|}
\hline S.No. & Parameters & $\begin{array}{l}\text { January } \\
\text { Avarage }\end{array}$ & $\begin{array}{c}\text { June } \\
\text { Average }\end{array}$ & $\begin{array}{l}\text { August } \\
\text { Average }\end{array}$ & $\begin{array}{l}\text { October } \\
\text { Average }\end{array}$ & $\begin{array}{c}\text { Yearly } \\
\text { Average }\end{array}$ \\
\hline 1 & Air temperature $\mathrm{C}$ & 18.38 & 38.17 & 31.91 & 31.52 & 29.99 \\
\hline 2 & Water temperature C & 15.50 & 31.25 & 29.95 & 26.73 & 25.86 \\
\hline 3 & DO \% Saturation $\mathrm{mg} / \mathrm{L}$ & 4.74 & 3.68 & 4.32 & 5.17 & 4.48 \\
\hline 4 & BOD mg/L & 8.46 & 7.16 & 6.33 & 6.02 & 6.99 \\
\hline 5 & COD mg/L & 32.93 & 32.98 & 42.14 & 31.09 & 34.79 \\
\hline 6 & pH & 7.57 & 7.81 & 7.75 & 8.03 & 7.79 \\
\hline 7 & Turbidity (NTU) & 15.14 & 22.27 & 81.23 & 30.70 & $\mathbf{3 7 . 3 3}$ \\
\hline 8 & Conductivity (mhos/cm) & 717.20 & 487.88 & 321.51 & 486.34 & 503.23 \\
\hline 9 & $\begin{array}{l}\text { Total Coliform } \\
(\mathrm{mpn} / 100 \mathrm{ml})\end{array}$ & $4.99 \mathrm{E}+07$ & $5.25 \mathrm{E}+06$ & $3.93 \mathrm{E}+05$ & $1.59 \mathrm{E}+05$ & $1.39 \mathrm{E}+07$ \\
\hline 10 & Hardness (mg/L of CaCO3) & 232.08 & 169.08 & 150.55 & 194.09 & 186.45 \\
\hline 11 & Alkalinity (mg/L of CaCO3) & 242.91 & 161.25 & 134.64 & 203.55 & 185.59 \\
\hline
\end{tabular}

Volume 5 Issue 6, June 2016 www.ijsr.net

Licensed Under Creative Commons Attribution CC BY 


\section{International Journal of Science and Research (IJSR)}

ISSN (Online): 2319-7064

Index Copernicus Value (2013): 6.14 | Impact Factor (2015): 6.391

Table 5: Consolidated Average Variation at Daruhera in the gap of 1994-2005

\begin{tabular}{|c|c|c|c|c|c|c|}
\hline S.No. & Parameters & $\begin{array}{l}\text { January } \\
\text { Avarage } \\
\end{array}$ & $\begin{array}{c}\text { June } \\
\text { Average }\end{array}$ & August Average & $\begin{array}{l}\text { October } \\
\text { Average } \\
\end{array}$ & $\begin{array}{c}\text { Yearly } \\
\text { Average } \\
\end{array}$ \\
\hline 1 & Air temperature $\mathrm{C}$ & 17.75 & 36.08 & 32.23 & 31.86 & 29.48 \\
\hline 2 & Water temperature $\mathrm{C}$ & 14.50 & 31.17 & 29.05 & 27.23 & 25.48 \\
\hline 3 & DO \% Saturation $\mathrm{mg} / \mathrm{L}$ & 3.49 & 4.02 & 3.20 & 2.99 & 3.43 \\
\hline 4 & BOD mg/L & 10.49 & 4.65 & 5.72 & 6.03 & 6.72 \\
\hline 5 & COD mg/L & 45.75 & 33.87 & 51.91 & 37.89 & 42.36 \\
\hline 6 & pH & 7.16 & 7.81 & 7.80 & 8.05 & 7.71 \\
\hline 7 & Turbidity (NTU) & 58.84 & 107.08 & 117.41 & 24.52 & 76.96 \\
\hline 8 & Conductivity (mhos/cm) & 481.58 & 378.43 & 360.55 & 509.27 & 432.46 \\
\hline 9 & $\begin{array}{l}\text { Total Coliform } \\
(\mathrm{mpn} / 100 \mathrm{ml})\end{array}$ & $6.61 \mathrm{E}+07$ & $3.51 \mathrm{E}+06$ & $1.88 \mathrm{E}+05$ & $3.65 \mathrm{E}+06$ & $1.84 \mathrm{E}+07$ \\
\hline 10 & Hardness (mg/L of CaCO3) & 194.23 & 116.42 & 129.82 & 203.82 & 161.07 \\
\hline 11 & Alkalinity (mg/L of CaCO3) & 206.50 & 135.33 & 131.73 & 210.36 & 170.98 \\
\hline
\end{tabular}
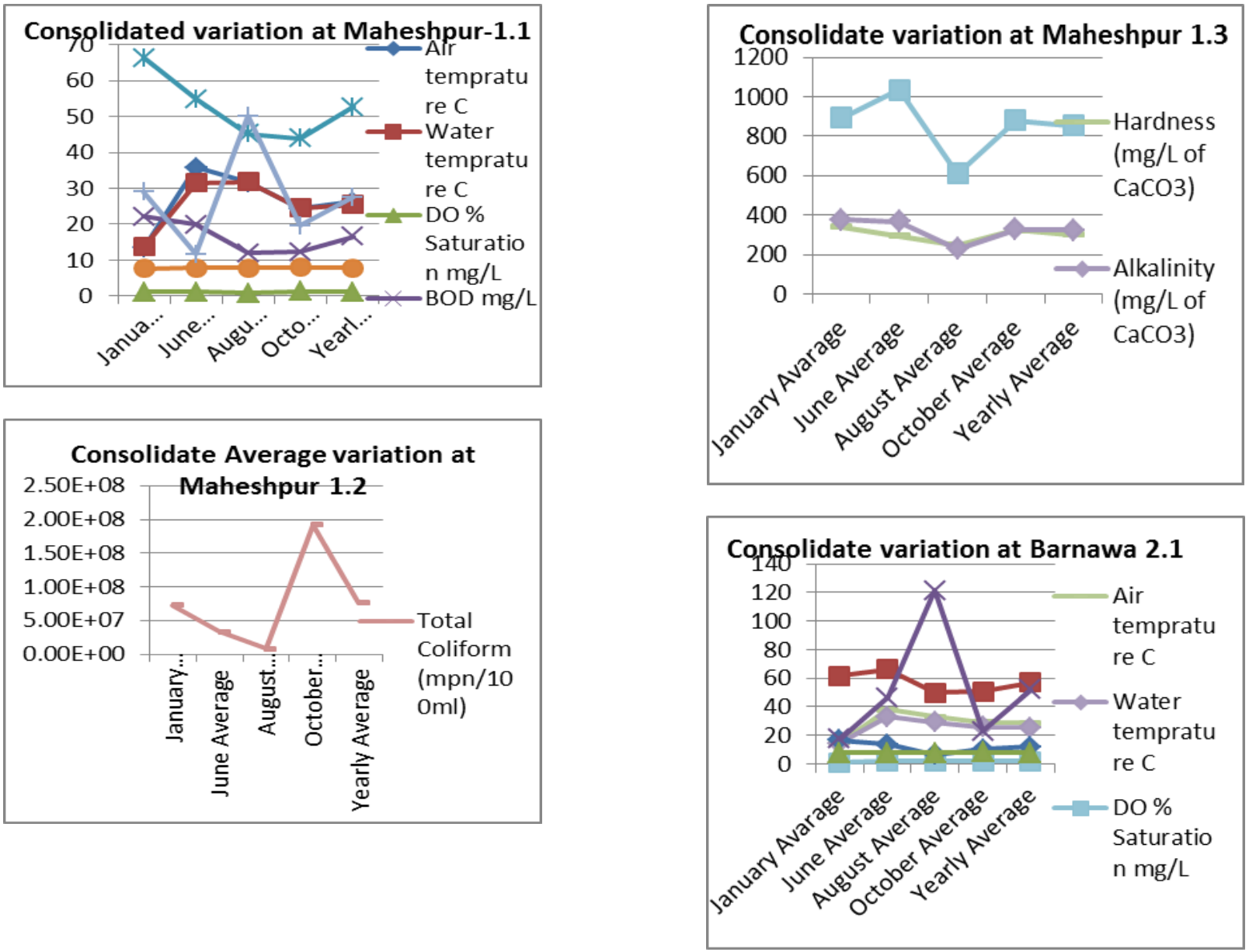

Volume 5 Issue 6, June 2016 www.ijsr.net

Licensed Under Creative Commons Attribution CC BY 


\section{International Journal of Science and Research (IJSR)}

ISSN (Online): 2319-7064

Index Copernicus Value (2013): 6.14 | Impact Factor (2015): 6.391
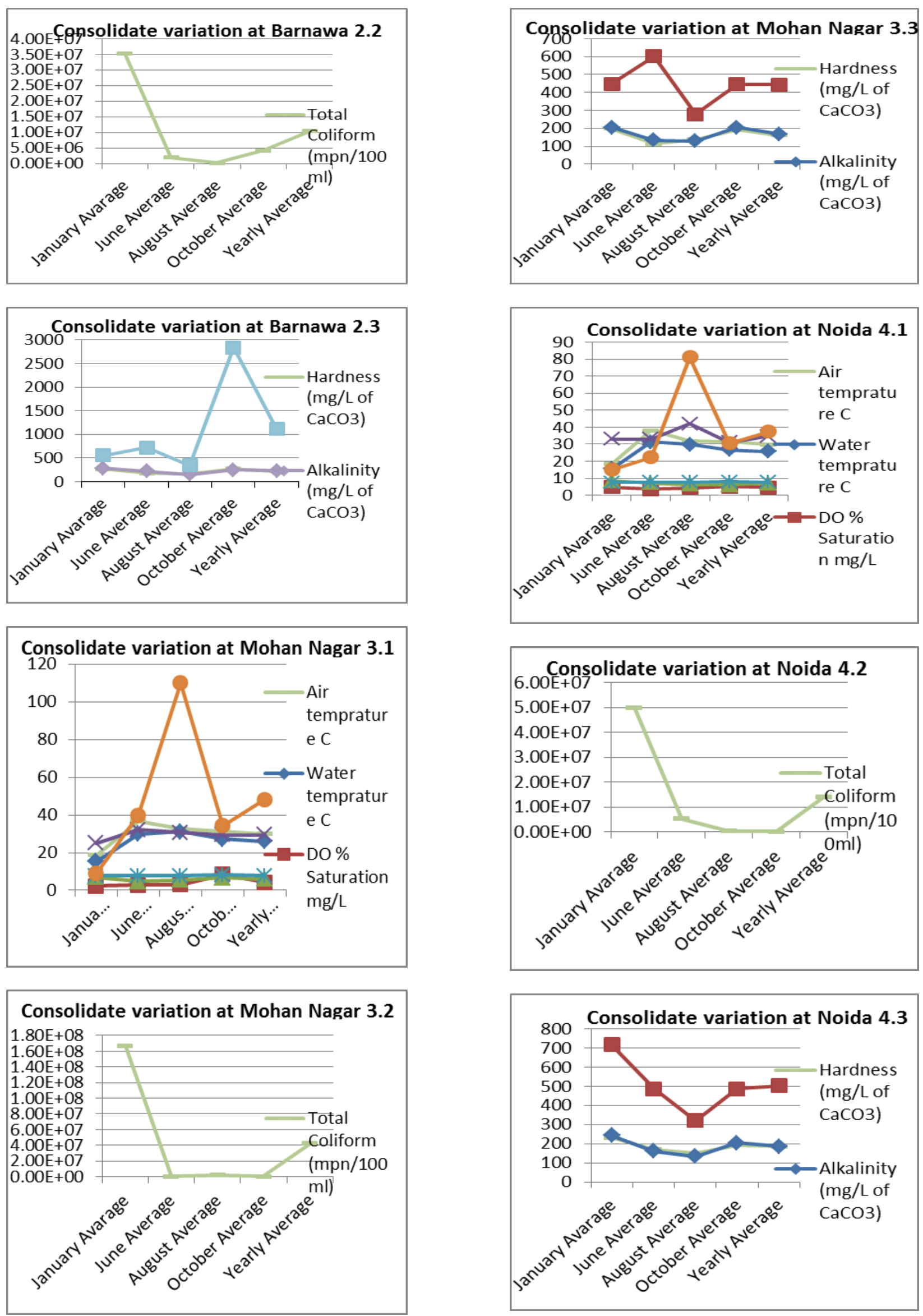

Volume 5 Issue 6, June 2016 www.ijsr.net

Licensed Under Creative Commons Attribution CC BY 
International Journal of Science and Research (IJSR)

ISSN (Online): 2319-7064

Index Copernicus Value (2013): 6.14 | Impact Factor (2015): 6.391
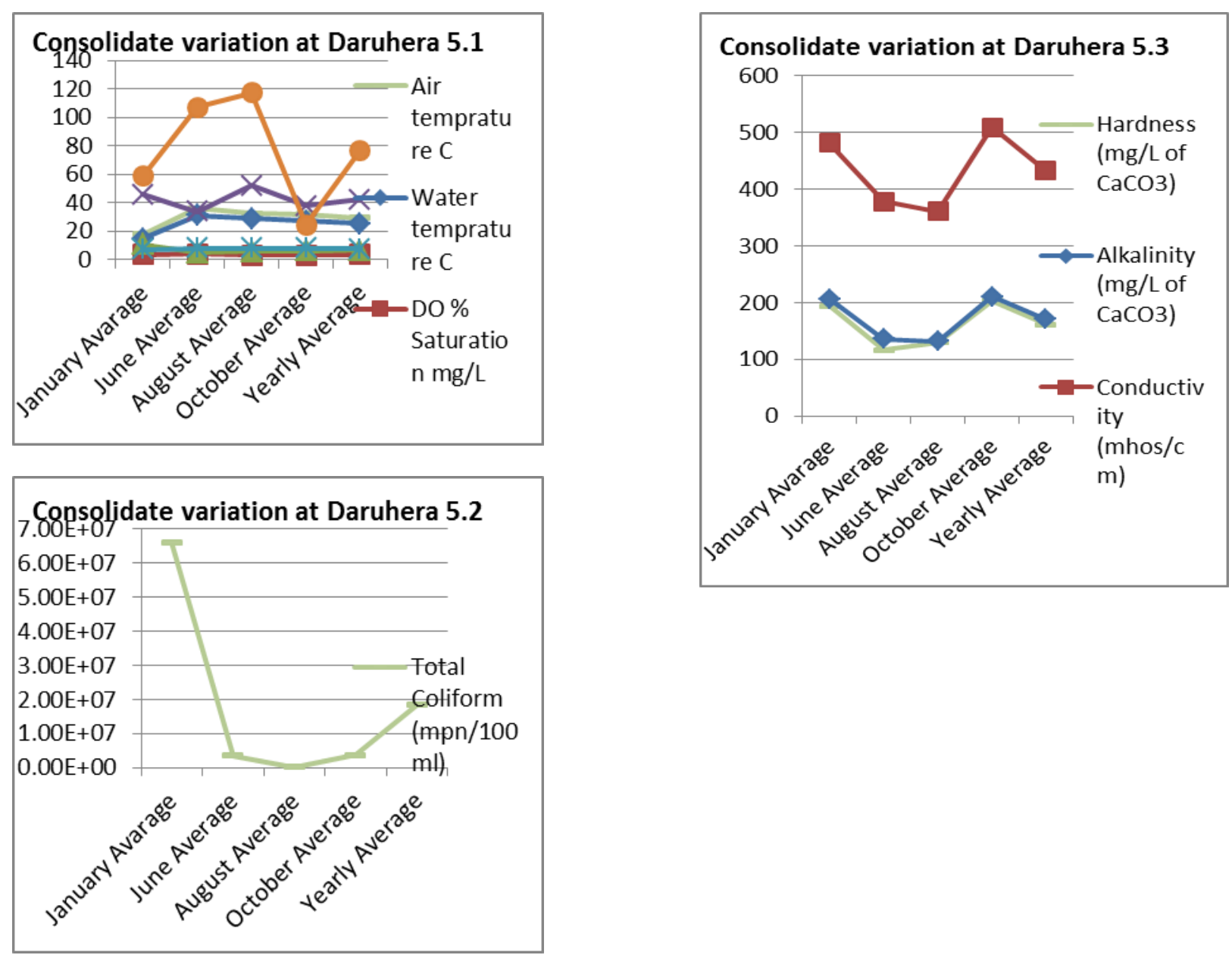

Volume 5 Issue 6, June 2016 www.ijsr.net

Licensed Under Creative Commons Attribution CC BY 